\title{
Performance of Baby Corn Varieties under Different Levels of Fertilizers during Summer Season
}

\author{
Dhabanita Medhi and Rinjumoni Dutta* \\ Department of Agronomy, Assam Agricultural University, India \\ *Corresponding author
}

\begin{tabular}{l} 
Ke y w o r d s \\
Baby corn, \\
$\begin{array}{l}\text { Varieties, Fertilizer } \\
\text { levels, Yield } \\
\text { attributing } \\
\text { characters, Yield }\end{array}$ \\
Article Info \\
$\begin{array}{l}\text { Accepted: } \\
10 \text { October } 2019 \\
\text { Available Online: } \\
\text { 10 November } 2019\end{array}$ \\
\hline
\end{tabular}

A B S T R A C T
A field experiment was conducted during the summer season of 2018 on sandy loam soil at the Instructional-cum-Research (ICR) Farm, Assam Agricultural University, Jorhat to study the outcome of three baby corn varieties (VL Baby corn-1, CMVL Baby corn -2 and G-5414) and four fertilizer levels (60-40-40 $\mathrm{N}-\mathrm{P}_{2} \mathrm{O}_{5}-\mathrm{K}_{2} \mathrm{O} \mathrm{kg} / \mathrm{ha}, 75-50-50 \quad \mathrm{~N}-\mathrm{P}_{2} \mathrm{O}_{5}-\mathrm{K}_{2} \mathrm{O} \mathrm{kg} / \mathrm{ha}, 90-60-60 \mathrm{~N}-\mathrm{P}_{2} \mathrm{O}_{5}-\mathrm{K}_{2} \mathrm{O}$ $\mathrm{kg} / \mathrm{ha}$ and 105-70-70 N-P $\mathrm{O}_{5}-\mathrm{K}_{2} \mathrm{O} \mathrm{kg} / \mathrm{ha}$ ). The treatments were laid out in split plot design and replicated thrice with varieties in the main plot and fertilizer levels in the sub-plot. Cobs per plant, cob weight with and without husk as well as cob yield with husk (86.07 q/ha) and without husk (18.78 q/ha) was higher for G-5414 where as plant height and cob length was higher for CMVL Baby corn-2. Dry matter production and LAI as well as yield attributing characters like number of cobs per plant, cob length and weight with and without husk as well as cob yield with husk (89.07 q/ha) and without husk (18.39 q/ha) and green fodder yield $(249.99 \mathrm{q} / \mathrm{ha})$ were the highest with the application of 105$70-70 \mathrm{~N}-\mathrm{P}_{2} \mathrm{O}_{5}-\mathrm{K}_{2} \mathrm{O} \mathrm{kg} / \mathrm{ha}$ which was at par with $90-60-60 \mathrm{~N}-\mathrm{P}_{2} \mathrm{O}_{5}-\mathrm{K}_{2} \mathrm{O} \mathrm{kg} / \mathrm{ha}$.

\section{Introduction}

Cultivating 'baby corn' is gaining wide popularity and currently grown almost throughout the world for its young, fresh, finger-like green ears, harvested at the time of silk emergence or before pollination and fertilization (Ramachandrappa et al., 2004) and also as green fodder for animal feed. Baby corn ears in light yellow colour with regular row arrangement, 10 to $12 \mathrm{~cm}$ long and a diameter of 1.0 to $1.5 \mathrm{~cm}$ arrangement are mostly preferred in the market (Golada et al., 2013) Its cultivation promises to have an important role in the future of crop production due to its fresh and safe product.

It has short growth duration and offers an intensive rotation cultivation system which is an excellent solution for promoting economic situation and alleviation of poverty especially in countries with high population problems. 
Varieties respond differently under different agro-climatic conditions which effects the suitability of a particular cultivar. Maize being a very exhaustive crop shows a positive response to application of fertilizers and as such adequately supplied balanced nutrients influences the yield of the crop (Gosavi and Bhagat, 2009 and Shrivastava and Sinha, 1992). Among the essential plant nutrients N, $\mathrm{P}$ and $\mathrm{K}$ play the key role in governing the quantity as well as quality production.

Nitrogen $(\mathrm{N})$ is a component of protein and nucleic acids and deficient or excess in supply both throughout the growing season can result in failure to achieve the desired production. Phosphorus plays an important part in many physiological processes and enzymatic reactions that occur within a developing and maturing plant. It also affects the grain quality and may increase the plant resistance to diseases. Potassium helps in enzyme activation, protein synthesis, photosynthesis, osmoregulation, stomatal movement, energy transfer, phloem transport, cation-anion balance, and stress resistance.

Thus, it is imperative to identify varieties suitable for a specific region along with balanced nutrient doses for boosting the growth and productivity especially under rain fed conditions and for these a field experiment was carried out to pinpoint the varieties and standardize a suitable fertilizer dose for baby corn cultivation in Assam during summer season.

\section{Materials and Methods}

\section{Experimental site}

The experimental site was well drained with uniform topography. The total precipitation during the crop period amounted to about $282.10 \mathrm{~mm}$. The soil of experimental plot was sandy loam in texture, acidic in reaction $(\mathrm{pH}-$
$5.15)$, medium in organic carbon $(0.68 \%)$, low in available $\mathrm{N}(198.19 \mathrm{~kg} / \mathrm{ha})$, medium in available $\mathrm{P}_{2} \mathrm{O}_{5}(27.48 \mathrm{~kg} / \mathrm{ha})$ and available $\mathrm{K}_{2} \mathrm{O}$ (158.23 kg/ha)

\section{Details of the treatments and experiment}

The experiment was laid out in split plot design using three baby corn varieties viz., VL Baby corn-1, CMVL Baby corn-2 and G-5414 in the main plot and four fertilizer levels viz., 60-40-40 N-P $\mathrm{O}_{5}-\mathrm{K}_{2} \mathrm{O} \mathrm{kg} / \mathrm{ha}, 75-50-50 \mathrm{~N}-$ $\mathrm{P}_{2} \mathrm{O}_{5}-\mathrm{K}_{2} \mathrm{O} \mathrm{kg} / \mathrm{ha}, 90-60-60 \mathrm{~N}-\mathrm{P}_{2} \mathrm{O}_{5}-\mathrm{K}_{2} \mathrm{O} \mathrm{kg} / \mathrm{ha}$ and 105-70-70 N- $\mathrm{P}_{2} \mathrm{O}_{5}-\mathrm{K}_{2} \mathrm{O} \mathrm{kg} / \mathrm{ha}$ in the sub plot and replicated thrice having each unit plot size of $4.00 \mathrm{~m} \mathrm{X} \square 3.6 \mathrm{~m}$.

The field was prepared for sowing by first ploughing with tractor-drawn disc plough followed by two harrowing and then leveling. All the stubbles and debris were thoroughly removed. The treatment combinations were applied randomly as per the statistical design. The seeds were sown on $23^{\text {rd }}$ February, 2018 maintaining a spacing of $45 \mathrm{~cm}$ X $20 \mathrm{~cm}$. Half of nitrogenous fertilizers (urea), full dose of phosphate (Single Superphosphate) and potassic (Muriate of Potash) fertilizers were applied as uniformly as possible before sowing of the seeds as per the treatment design. The rest half of the nitrogenous fertilizer (urea) was applied as top dressing during the time of earthing up. The crops were raised in accordance to the recommended package of practices.

\section{Observations recorded}

Five plants were randomly selected from each plot leaving the border rows and growth parameters were recorded in at 30 DAS, 60 DAS and at the time of harvest of the cob. The LAI was measured using Plant Canopy Analyzer (Model No. 2200) and was calculated by the following formula as given by Watson (1952): 
Leaf area index (LAI)

Total leaf area

\section{Ground area}

The number of cobs per plant, cob length and weight with husk and without husk were recorded from each plot by picking cobs from five randomly selected labeled plants. Yield from each plot was recorded and converted to quintal per hectare. After picking of the cobs, the green plant were cut close to the ground and weighed and per plot yield was then converted to quintal per hectare.

\section{Statistical analysis}

The recorded data for each parameter were statistically analyzed using analysis of variance for split-plot design (SPD) as given by Panse and Sukhatma (1985). For significant ' $F$ ' test, critical difference (CD) was reported at 5 per cent probability level otherwise only S.Em. $( \pm)$ was denoted.

\section{Results and Discussion}

\section{Effect of varieties}

\section{Growth parameters}

The varieties did not exert any significant impact in terms of plant height and dry matter production at 30 DAS and Leaf Area Index (LAI) at all the growth stages. However, plant height and dry matter production differed significantly among the varieties at 60 DAS and at the time of harvest. At 60 DAS, the variety CMVL Baby corn-2 had higher plant height $(148.61 \mathrm{~cm})$ which was comparable with the variety G-5414(146.85cm) but significantly higher than the variety VL Baby corn-1 $(143.14 \mathrm{~cm})$. Similar observations were also recorded at the time of harvest. G-5414 recorded the highest dry matter production both at 60 DAS and at harvest which was at par with CMVL Baby corn-2. This difference could be attributed to genetic potential of different varieties. Similar findings were also reported by Pandey et al., (2002) and Kumer et al., (2015) (Table 1).

VL Baby corn -1 took lesser days for tasseling, silking and harvest initiation compared to the other varieties because of its shorter vegetative growth period. These results substantiate the findings of Sukanya et al., (1998) and Archana and Lalitha (2015) where varietal variation gave edge to differences in growth characters among different varieties.

\section{Yield attributing characters}

Number of cobs per plant and cob girth was higher in G-5414 whereas cob length was higher for the variety CMVL Baby corn-2. More number of cobs per plant and higher girth diameter recorded with G-5414 and higher cob length recorded with CMVL Baby corn-2 could be attributed to its genetic constitution and potential.

Similar findings were recorded by Thakur et al., (1998) and Archana and Lalitha (2015). Weight of each cob with and without husk was recorded the highest for the variety G-5414 followed by CMVL Baby corn-2. In most of the cereals viz., corn, the greater assimilating surface at reproductive development stage results in adequate production of metabolites and their translocation towards the corn leading to higher weight (Golada et al., 2013). Similar varietal difference in regard to cob weight with and without husk was accorded by Pandey et al., (2002) and Sahoo (2011).

\section{Baby corn yield and green fodder yield}

Cob yield (with and without husk) was recorded the highest in G-5414 compared to VL Baby corn-1 but was at par with the variety CMVL Baby corn-2. Higher cob yield 
realized with G-5414 compared to CMVL Baby corn-2 and VL Baby corn-1 could be attributed to genetic character of the different varieties making differences in the partitioning of photosynthates between them.

Besides more number of cobs per plant produced by G-5414 and higher weight of each cob than the other two varieties might have increased the cob yield as number of cobs per plant and weight of each cob are vital yield attributing character. Similar differences in cob yield owing to different varieties were recorded by Pandey et al., (2000), Ramachandrudu et al., (2013), Asaduzzaman et al., (2014) and Kumer et al., (2015).

\section{Effect of fertilizer levels}

\section{Growth parameters}

The plant height was significantly higher with the application of 105-70-70 N- $\mathrm{P}_{2} \mathrm{O}_{5}-\mathrm{K}_{2} \mathrm{O}$ $\mathrm{kg} / \mathrm{ha}$ followed by application of 90-60-60 N$\mathrm{P}_{2} \mathrm{O}_{5}-\mathrm{K}_{2} \mathrm{O} \mathrm{kg} / \mathrm{ha}$. Higher levels of fertilizers led to better metabolic activities performed by the plant which might have played a vital role in photosynthesis translocation as well as protein synthesis, simulation of root growth, activation of plant enzyme and many other processes ultimately leading to vigorous growth of the plant. The increased in plant height with increasing levels of fertilizers was also reported by Thakur et al., (1997) and Singh (2001) (Table 2).

Dry matter production and LAI was higher with the application of 105-70-70 N-P $\mathrm{P}_{2} \mathrm{O}_{5}$ $\mathrm{K}_{2} \mathrm{O} \mathrm{kg} / \mathrm{ha}$ which was at par with the application of $90-60-60 \mathrm{~N}-\mathrm{P}_{2} \mathrm{O}_{5}-\mathrm{K}_{2} \mathrm{O} \mathrm{kg} / \mathrm{ha}$ at 60DAS and at harvest. As the supply of nutrients particularly nitrogen in the soil increases, a greater proportion of nitrogen was absorbed and translocated to the shoot and assimilated there. It is the known fact that nitrogen is the constitutional compound of the chloroplasts. More amount of nitrogen lead to enhanced cell division and cell elongation which might have influence on leaf emergence and its expansion. Hence, more values were obtained at higher levels of nitrogen.

The increase with increasing levels of fertilizers is in conformity with the findings of Thakur et al., (1997) and Kumar et al., (2008).

Dry matter production is a result of metabolic activities of the crop plant. With increase levels of fertilizers, there was increase in plant height and LAI which contributed to more photosynthetic rate and accumulation of photosynthates. Thus with increase levels of fertilizers dry matter production also increased. This finding corroborates the findings of Luikham et al., (2003) and Sobhana et al., (2012).

\section{Yield attributing characters}

Yield attributing characters like number of cobs per plant, length and weight of the cob with and without husk showed a positive response to the increasing levels of fertilizers doses and in all the cases the highest values were recorded with the application of 105-70$70 \mathrm{~N}-\mathrm{P}_{2} \mathrm{O}_{5}-\mathrm{K}_{2} \mathrm{O} \mathrm{kg} / \mathrm{ha}$ which was at par with the application of 90-60-60 N- $\mathrm{P}_{2} \mathrm{O}_{5}-\mathrm{K}_{2} \mathrm{O}$ $\mathrm{kg} / \mathrm{ha}$. More growth at higher fertilizer levels might have resulted in rapid leaf expansion and LAI. This could have resulted in production of more photosynthates and translocation of these photosynthates to sink.

Higher source-sink relationship which resulted in enhanced supply of photosynthates consequently resulted in better growth parameters and higher accumulation of dry matter in baby corn plants thus improving the values of yield attributes with each successive increase in fertilizer dose. 
Table.1 Effect of varieties and levels of fertilizers on growth parameters

\begin{tabular}{|c|c|c|c|c|c|c|c|c|c|}
\hline \multirow[t]{2}{*}{ Treatments } & \multicolumn{3}{|c|}{ Plant height (cm) } & \multicolumn{3}{|c|}{ LAI (Leaf Area Index) } & \multicolumn{3}{|c|}{ Dry matter production (g/plant) } \\
\hline & 30 DAS & 60 DAS & At Harvest & 30 DAS & 60 DAS & $\begin{array}{c}\text { At } \\
\text { Harvest }\end{array}$ & 30 DAS & 60 DAS & $\begin{array}{c}\text { At } \\
\text { Harvest }\end{array}$ \\
\hline \multicolumn{10}{|c|}{ Varieties } \\
\hline VL Baby corn-1 & 41.43 & 142.84 & 164.68 & 1.69 & 5.10 & 5.78 & 13.59 & 39.52 & 57.85 \\
\hline $\begin{array}{c}\text { CMVL Baby corn } \\
-2\end{array}$ & 43.20 & 149.28 & 172.62 & 1.72 & 5.17 & 5.88 & 14.72 & 43.93 & 62.02 \\
\hline G-5414 & 42.43 & 147.10 & 169.68 & 1.80 & 5.35 & 5.94 & 15.03 & 45.37 & 64.28 \\
\hline S.Em. \pm & 0.52 & 0.82 & 0.77 & 0.08 & 0.07 & 0.08 & 0.39 & 0.66 & 0.74 \\
\hline C.D. $(P=0.05)$ & NS & 3.22 & 3.04 & NS & NS & NS & NS & 2.60 & 2.89 \\
\hline \multicolumn{10}{|c|}{ Levels of fertilizers $\left(\mathrm{N}-\mathrm{P}_{2} \mathrm{O}_{5}-\mathrm{K}_{2} \mathrm{O} \mathrm{kg} / \mathrm{ha}\right)$} \\
\hline $60-40-40$ & 41.44 & 141.76 & 164.99 & 1.70 & 4.86 & 5.64 & 12.81 & 37.48 & 55.81 \\
\hline 75-50-50 & 41.88 & 144.87 & 167.32 & 1.72 & 5.11 & 5.81 & 13.91 & 41.15 & 59.92 \\
\hline $90-60-60$ & 42.70 & 148.25 & 170.80 & 1.75 & 5.39 & 5.98 & 15.10 & 45.23 & 64.01 \\
\hline 105-70-70 & 43.41 & 150.74 & 172.85 & 0.77 & 5.46 & 6.02 & 15.96 & 47.91 & 65.79 \\
\hline S.Em. \pm & 0.56 & 0.68 & 0.67 & 0.06 & 0.08 & 0.05 & 0.78 & 1.19 & 1.26 \\
\hline C.D. $(P=0.05)$ & NS & 2.03 & 1.98 & NS & 0.24 & 0.15 & NS & 3.54 & 3.75 \\
\hline Interaction & NS & NS & NS & NS & NS & NS & NS & NS & NS \\
\hline
\end{tabular}


Table.2 Effect of varieties and levels of fertilizers on yield attributing characters and yield

\begin{tabular}{|c|c|c|c|c|c|c|c|c|c|}
\hline \multirow[t]{2}{*}{ Treatments } & \multirow{2}{*}{$\begin{array}{l}\text { No. of } \\
\text { cobs per } \\
\text { plant }\end{array}$} & \multicolumn{2}{|c|}{ Cob weight (g) } & \multicolumn{2}{|c|}{ Cob length $(\mathrm{cm})$} & \multirow{2}{*}{$\begin{array}{l}\text { Baby corn } \\
\operatorname{girth}(\mathbf{c m})\end{array}$} & \multicolumn{2}{|c|}{ Cob yield(q/ha) } & \multirow{2}{*}{$\begin{array}{c}\text { Green } \\
\text { fodder yield } \\
\text { (q/ha) }\end{array}$} \\
\hline & & $\begin{array}{l}\text { With } \\
\text { husk }\end{array}$ & $\begin{array}{c}\text { Without } \\
\text { husk }\end{array}$ & $\begin{array}{l}\text { With } \\
\text { husk }\end{array}$ & $\begin{array}{c}\text { Without } \\
\text { husk }\end{array}$ & & $\begin{array}{l}\text { With } \\
\text { husk }\end{array}$ & $\begin{array}{c}\text { Without } \\
\text { husk }\end{array}$ & \\
\hline \multicolumn{10}{|c|}{ Varieties } \\
\hline VL Baby corn-1 & 2.45 & 36.67 & 8.18 & 19.82 & 6.84 & 1.36 & 81.14 & 14.92 & 235.54 \\
\hline $\begin{array}{l}\text { CMVL Baby } \\
\text { corn -2 }\end{array}$ & 2.48 & 39.17 & 8.39 & 22.67 & 8.57 & 1.33 & 84.67 & 17.77 & 247.02 \\
\hline G-5414 & 3.00 & 41.04 & 8.56 & 21.65 & 8.14 & 1.46 & 86.07 & 18.78 & 249.99 \\
\hline S.Em. \pm & 0.04 & 0.52 & 0.05 & 0.39 & 0.16 & 0.03 & 0.80 & 0.27 & 0.86 \\
\hline C.D. $(P=0.05)$ & 0.16 & 2.05 & 0.13 & 1.54 & 0.60 & 0.09 & 3.14 & 1.05 & 3.37 \\
\hline \multicolumn{10}{|c|}{ Levels of fertilizers $\left(\mathrm{N}-\mathrm{P}_{2} \mathrm{O}_{5}-\mathrm{K}_{2} \mathrm{O} \mathrm{kg} / \mathrm{ha}\right)$} \\
\hline $60-40-40$ & 2.32 & 36.14 & 8.16 & 19.51 & 7.02 & 1.36 & 77.89 & 15.50 & 233.17 \\
\hline $75-50-50$ & 2.57 & 38.04 & 8.31 & 21.16 & 7.63 & 1.37 & 82.29 & 16.80 & 240.15 \\
\hline $90-60-60$ & 2.80 & 40.31 & 8.46 & 22.23 & 8.23 & 1.40 & 86.57 & 17.95 & 246.72 \\
\hline 105-70-70 & 2.88 & 41.35 & 8.58 & 22.60 & 8.51 & 1.42 & 89.07 & 18.39 & 249.99 \\
\hline S.Em. \pm & 0.07 & 0.58 & 0.05 & 0.28 & 0.17 & 0.02 & 1.20 & 0.28 & 1.81 \\
\hline C.D. $(P=0.05)$ & 0.21 & 1.73 & 0.14 & 0.83 & 0.50 & NS & 3.56 & 0.81 & 5.33 \\
\hline Interaction & NS & NS & NS & NS & NS & NS & NS & NS & NS \\
\hline
\end{tabular}

*NS = Non-significant 
Superiority in yield attributing characters like number of cobs per plant length and weight of the cob with and without husk with increasing doses of fertilizer levels have also been confirmed by Pandey et al., (2002) and Sobhana et al., (2012) which supports the results of the present findings.

\section{Baby corn yield and green fodder yield}

Application of 105-70-70 N-P $\mathrm{P}_{2} \mathrm{O}_{5}-\mathrm{K}_{2} \mathrm{O} \mathrm{kg} / \mathrm{ha}$ recorded the highest cob yield with and without husk and green fodder yield which was at par with the application of 90-60-60 N$\mathrm{P}_{2} \mathrm{O}_{5}-\mathrm{K}_{2} \mathrm{O} \mathrm{kg} / \mathrm{ha}$. Yield of a crop is a function of several yield components. The increase in fertilizer levels led to more availability of nutrients in the soil enabling the plant to absorb more nutrients and moisture which empowered the plant to manufacture more quantities of photosynthates and accumulating them in sink. Besides, positive response of yield attributing characters such as number of cobs per plant, cob girth and length and cob weight at higher levels of fertilizer doses also attributed to higher cob yield. Similar findings of response of crop to higher fertilizer levels were also reported by Singh (2001), Sobhana et al., (2012) and Kumer et al., (2015).

Increased in fodder yields under the influence of higher levels of fertilizer doses might be on account of increase in plant height, number of functional leaves, Leaf Area Index (LAI) and dry matter accumulation at successive stages of crop growth. These results are in validation with the findings of Rajanna et al., (2006).

G-5414 exhibited better results in terms of growth parameters such as the highest plant height and dry matter production, yield attributing characters like cobs per plant, cob girth weight with and without husk as well as higher corn yield and green fodder yield. Application of 90-60-60 N-P $\mathrm{P}_{2} \mathrm{O}_{5}-\mathrm{K}_{2} \mathrm{O} \mathrm{kg} / \mathrm{ha}$ dose of fertilizers considerably resulted in better crop growth, yield attributes as well as yield. Thus, the maximum yield both with and without husk during summer season can be obtained by sowing of G-5414 baby corn variety with the application of 90-60-60 N$\mathrm{P}_{2} \mathrm{O}_{5}-\mathrm{K}_{2} \mathrm{O} \mathrm{kg} / \mathrm{ha}$

\section{References}

Archana, C.R. and Lalitha, B.E.K. 2015. Influence of varieties and spacing on yield of dual purpose baby corn (Zea mays L.) in summer rice fallows of Kerala. Journal of Tropical Agriculture. Vol-2

Asaduzzaman, M., Biswa, M., Islam, N., Rahman, M., Begum, R., Rahman, A. and Sarkar, M.A. 2014. Variety and NFertilizer Rate Influence the Growth, Yield and Yield Parameters of Baby Corn (Zea mays L.). Journal of Agricultural Science. 6(3):118-131

Golada, S.L., Sharma, G.L. and Jain, H.K. 2013. Performance of baby corn (Zea mays L.) as influenced by spacing, nitrogen fertilization and plant growth regulators under sub humid condition in Rajasthan, India. African Journal of Agricultural Research. 8(12):11001107

Gosavi, S.P. and Bhagat, S.B. 2009. Effect of nitrogen levels and spacing on yield attributes, yield and quality parameters of baby corn (Zea mays). Ann. Agric. Res. 30(3-4): 125-128

Kumar, A.K., Sagar, G.K., Chandrika, V. and Reddy, P.M. 2008. Effect of integrated nitrogen management on growth, yield and quality of baby corn. Crop Research 36(1/3): 60-62.

Kumer, M., Sukhchan and Brar, S.P.S. 2015. Evaluation of baby corn varieties for forage yield and various other traits in maize. Forage Res. 41 (1): 53-55

Luikham, E.R., Rajan, J.K., Rajendran, K. and Anal, P.S.M. 2003. Effect of organic 
and inorganic nitrogen on growth and yield of baby corn (Zea mays L). Agric. Sci. Digest 23(1): 19-21

Pandey, A. K., Ved, P., Mani, V. P. \& Singh, R. D. (2000). Effect of rate of nitrogen and time of application on yield and economics of baby corn (Zea mays L.). Indian Journal of Agronomy.45:338-34

Pandey, A.K., Mani, V.P., Prakash, V., Singh, R.D. and Gupta, H.S. 2002. Effect of varieties and plant densities on yield, yield attributes and economics of baby corn (Zea mays). Indian Journal of Agronomy. 47(2): 221-226.

Panse, V.G. and Sukhatma, P.V. 1985. Statistical methods for agricultural workers. ICAR Publication, New Delhi, pp.336-340

Rajanna, A.E., Ramachandrappa, B.K., Nanjappa, H.V and Saumya, T.M. 2006. Soil plant water status and yield of baby corn (Zea mays L.) as influenced by irrigation and fertility levels. Mysore Journal of Agricultural Sciences.40(1):74-82

Ramachandrudu, K., Priyadevi, S., Korikanthimath, V.S. 2013. Performance of baby corn varieties under agro-climatic conditions of Goa.Indian Journal of Horticulture.
70(1):139-140

Sahoo, S.C. 2011. Yield and economics of baby corn (Zea mays L.) as affected by varieties and levels of Nitrogen. Range Management and Agroforestry. 32(2): 135-137

Singh, S.D. 2001. Effect of irrigation regimes and nitrogen levels on growth, yield and quality of baby corn. Madras Agricultural Journal. 88(7-9): 367370.

Sobhana, V., Kumar, A., Idnani, L. K., Singh, I. and Shivadhar. 2012. Plant population and requirement for baby corn hybrids (Zea mays). Indian Journal of Agronomy. 57(3): 294-296.

Sukanya, T.S., Nanjappa, H.V. and Shivaleela, H.S. 1998. Growth parameters and yield of baby corn as influenced by varieties and spacing. Mysore Journal of Agricultural Sciences. 32: 264-268

Thakur, D. R, Prakash, O.M., Kharwara, P.C. and Bhalla S.K. 1997. Effect of nitrogen and plant spacing on growth, yield and economics of babycorn (Zea mays L). Indian Journal of Agronomy. 42(3): 479-483

Watson, D. J. 1952. The physiological basis of variation in yield. Adv. Agron. 4: 101145.

\section{How to cite this article:}

Dhabanita Medhi and Rinjumoni Dutta. 2019. Performance of Baby Corn Varieties under Different Levels of Fertilizers during Summer Season. Int.J.Curr.Microbiol.App.Sci. 8(11): 933-940. doi: https://doi.org/10.20546/ijcmas.2019.811.109 